\title{
Bride abduction in post-Soviet Central Asia: marking a shift towards patriarchy through local discourses of shame and tradition
}

Cynthia Werner Texas A\&M University

The apparent revival of non-consensual bride abduction in Kazakhstan and Kyrgyzstan is somewhat surprising seventy years after the Soviet state banned the practice and introduced sweeping legislation to emancipate women. This article relies on local discourses of shame and tradition to explain changing marriage practices and to mark a shift towards greater patriarchy in post-Soviet Central Asia. Discourses of shame are mobilized by local actors in support of the popular view that a woman should 'stay' after being abducted. Women can and do resist abductions, but they risk dealing with the burden of shame. Further, in Kyrgyzstan, where bride abduction is increasingly re-imagined as a national tradition, women and activists who challenge this practice can be viewed as traitors to their ethnicity. In post-Soviet society, these discourses of shame and tradition have helped men assert further control over female mobility and female sexuality.

My first encounter with bride abduction took place in 1994 while I was conducting fieldwork in a rural town in southern Kazakhstan. I was living with a Kazakh family when the neighbour's 18-year-old daughter, Raisa, was abducted by a stranger who lived in a nearby village and wanted to marry her. ${ }^{1} \mathrm{~A}$ few months later, my host family's 19-year-old daughter, Aigul, was abducted by her college boyfriend. Although the Soviet Union established laws banning forced marriages in the 1920s, these two experiences revealed that bride abductions were a reality in the 1990 and that they varied greatly from one case to the next. While Raisa was surprised and upset by the abduction, Aigul conspired in her own kidnapping in order to avoid a marriage that her parents preferred.

In a previous article, I have described the rise of bride abduction in the post-Soviet period, the different motives used to explain this practice, and the varying levels of consent (Werner 2004a). Relying on ethnographic accounts of bride abduction in southern Kazakhstan, the following article gives voice to Kazakh women and men who have experienced social transformations throughout the Soviet and post-Soviet periods. In the first section, I provide a cross-cultural framework for understanding bride abduction and present two stories of non-consensual bride abduction in contemporary Kazakhstan. I then provide a brief historical overview of marriage practices and gender relations among the Kazakhs in the pre-Soviet and Soviet eras. In the final 
sections, I look at how discourses of shame and tradition mark a shift towards greater patriarchy. I use marriage practices as a prism for understanding how Kazakh 'culture' is being dissected and reconstructed by local actors in ways that are shifting power relations between men and women.

I focus on two issues related to bride abduction that are contested by local community members. First, there is the question of what a young woman should do after she has been abducted against her will. Combining anthropological theories on honour and shame (Abu-Lughod 1986, 1993; Wikan 2008) with feminist understandings of gender-based violence (Mani 1998; Maynard 1993), I argue that cultural values related to honour and shame have been mobilized in a way that justifies the popular view that a woman should 'stay' after being abducted, and that these views help men assert further control over female mobility and female sexuality in the post-Soviet period. Borrowing Foucault's notion of resistance, however, I demonstrate that in a variety of ways Kazakh women are resisting the power that comes from shame. Second, there is the issue of whether bride abduction is an 'authentic' tradition in Kazakh and Kyrgyz society. A significant difference exists between attitudes in Kazakhstan, where nonconsensual bride abduction is not perceived to have strong ties to the past, and views in Kyrgyzstan, where non-consensual bride abduction is defended as a national 'tradition' with long historical roots. In Kyrgyzstan, international and local activists have challenged the historical legitimacy of this practice, arguing that its current manifestations are a violation of human rights. This localized debate relates to broader anthropological concerns about the conflict between cultural relativism and human rights issues (Merry 2006) and the relationship between narratives of the past and politics of the present (Anagnost 1997). Owing to the belief in the historical legitimacy of bride abduction, combined with values related to honour and shame, I also argue that male control over female mobility and female sexuality has become more pronounced in Kyrgyzstan, as reflected by higher rates of non-consensual bride abductions.

\section{Bride abduction: universal patterns, particular realities}

Bride abduction is a marriage practice that has been found in settings across Europe, Asia, Africa, Australia, and the Americas (Ayres 1974; Barnes 1999; McLennan 1970 [1865]). In a cross-cultural analysis, Barbara Ayres (1974) distinguishes four different marriage practices that involve the abduction of a bride. According to her typology, 'wife raiding' involves a daring attack in which the men from one community jointly steal women from another community. With 'genuine bride theft', the groom targets a specific woman, usually from his own community; the groom's family provides the bride's family with an apology or compensation; and the groom's family usually establishes affinal relations with the bride's family after the abduction. In the case of 'mock bride theft', the bride, pretending to resist her captors, appears to be a helpless victim and obedient daughter, whereas in reality she is eloping by choice. Finally, with 'ceremonial capture', the abduction is a ritual performance that takes place with the full knowledge and consent of the bride and her family members. In many societies, several of these practices can coexist at any given time. This is the case with Kazakhstan and Kyrgyzstan, where wife raiding is absent, but genuine bride theft, mock bride theft, and ceremonial capture are all present in the contemporary period.

In the Kazakh language, these three related practices are referred to with the single term qyz alyp qashu, which translates literally as 'take the girl and run'. Both abduction cases mentioned in the introduction would be categorized as qyz alyp qashu marriages, 
even though the latter case might be better described as an 'elopement' in the English language. In his study of bride abductions among the Yoruk of Turkey, Bates (1974: 272) observes a similar conflation of terms, and argues that the two forms of abductions are not distinguished linguistically because the abduction is regarded as an attack on the bride's family's honour and property (whether or not the bride consents). In modern Kazakh society, where views towards abduction are conflicted, the language allows a distinction between a non-consensual abduction (kelisimsiz qyz alyp qashu) and a consensual abduction (kelisimmen qyz alyp qashu). As I discuss further below, whether the abduction is consensual or not, it is the abduction itself that damages the family's honour and the bride's acceptance of the marriage serves to restore that honour.

Recent studies of these marriage practices in Central Asia use the term 'bride kidnapping' as the English-language translation for qyz alyp qashu in Kazakh and kyz ala kachuu in Kyrgyz (Handrahan 2000; 2004; Kleinbach 2003; Kleinbach, Ablezova \& Aitieva 2005; Kleinbach \& Salimjanova 2007; Werner 2004a). The terms 'nonconsensual kidnapping' and 'consensual kidnapping' are used in English to indicate the sub-categories in the local languages. ${ }^{2}$ As in the case of 'female circumcision', the act of naming this practice requires careful consideration (Walley 2006). For example, the term 'bride kidnapping' is based on a verb that originated in reference to the illegal abduction of children for labour or ransom, and therefore contains subtle implications that the bride is a child (or child-like) and that she might be held for ransom. Central Asian brides are usually 17 or older so they are not quite children anymore, and ransom never comes into play. One alternative term, 'bride theft', suggests that the bride is a type of property that can be stolen, while another alternative, 'bride capture, conveys the image of a bride being captured as a prize in a contest. In this article, I have decided to use the term 'bride abduction' because it is less problematic than the other terms.

In other cultures where bride abduction has been documented in the past, evidence suggests that the practice has abated or ended with the emergence of modern laws and social norms (Ahearn 2001; McLaren 2001). The opposite is true in Central Asia, where forced abductions have become increasingly common since the fall of the Soviet Union, particularly in Kyrgyzstan and Kazakhstan (Amsler \& Kleinbach 1999; Werner 2004a). In a typical forced abduction, the groom and several male friends use force or deception to abduct a woman and take her to the groom's home. She is then pressured by the groom's female relatives to accept the marriage and to write a letter to her parents. The apparent resurgence of bride abduction is somewhat surprising seventy years after the Soviet state banned the practice and introduced sweeping legislation to emancipate women.

Bride abduction has gained more international notoriety in Kyrgyzstan, where it occurs more frequently and is more geographically dispersed than in Kazakhstan, where it is locally perceived to be concentrated in Southern Kazakhstan province (Kleinbach 2003; Werner 2004a). In each case of bride abduction, there is an established sequence of events that is remarkably similar in both countries. Every instance, however, has its own peculiarities, including the details regarding who participates in the abduction, why the groom chooses to abduct a particular bride at a particular time, and how the bride and her family respond to the abduction. The two stories presented below describe what 'typically' happens when a bride is abducted against her will, and illustrate the cultural pressure that women receive regarding their decision to accept the marriage. ${ }^{3}$ 
One night, a loud knocking at the door woke me from a deep sleep. Everybody in the house got up to greet our close neighbours, Serikzhan and Baqyt, and we all drank tea as they recounted their disturbing news. Their 18-year-old daughter, Raisa, was missing and they suspected that she had been abducted. The third daughter in a family with seven girls and one boy, Raisa had recently completed high school and, like most young and unmarried women, she still lived at home. Serikzhan and Baqyt did not know what to do, but they were hoping that we knew something about her whereabouts, and they mentioned that they might need to borrow my host family's car. A few hours later, a small group of men arrived at their house to 'apologize' for the fact that their relative had abducted Raisa, and thus it was confirmed that Raisa had indeed been abducted by a man who intended to marry her. These men even brought an 'apology' (keshirim) payment in lieu of the bridewealth. Following custom, Raisa's parents sent several relatives, including another daughter, to check on her condition.

When her relatives returned the next day, they recounted Raisa's version of the events. On the evening of the abduction, she was home with her younger siblings while her parents were attending a dinner party at a nearby house. While Raisa was outside washing clothes, four young men entered her family's fenced compound. They grabbed her, forcefully placed her inside a waiting car, and drove a few kilometres to a nearby village. She recognized one of the men from school, and wondered whether he was the one who was abducting her. When the car arrived at its final destination, however, she learned that she was being abducted by a stranger who had apparently fallen in love with her at first sight, after seeing her one day at the local bazaar. She had not noticed this stranger, Berik, before, and they had never so much as exchanged a few words. Through his friends, Berik learned enough about her to know that he wanted to marry her. He also found out where she lived, and planned the abduction with the help of friends and relatives.

His parents supported this decision, and looked forward to having a daughter-in-law to help with household chores. While he and his friends were abducting Raisa, his parents were preparing a celebration at the home that they shared with Berik. His parents and relatives greeted Raisa upon her arrival. The women ushered her into the house, where they offered her a marriage scarf and tried to convince her to stay. As Raisa explained to her relatives, she was not initially happy with this marriage at all. She resented the fact that he was significantly older at 27 years of age. He also lived with his elderly parents, and she was concerned that nobody in the household received a reliable income. Nevertheless, his female relatives pressured her to accept the marriage, and she acquiesced, not wanting to deal with the shame of being a 'girl who returned home'. Although they were extremely upset, her parents agreed that this was the right decision.

In the end, Raisa's story has a happy ending. Several years after she was married, I met with her while she, now with her first child, was visiting her parents. She told me that her husband and his parents treated her well, and that she was very satisfied with her marriage. In this regard, her experience differs from women who are abducted by men who then proceed to abuse them physically. There is limited information available for understanding women's experiences after being abducted.

Knowing my interest in bride abductions, one of my friends introduced me to one of her co-workers named Gulmira who lived in the small city of Turkestan. Gulmira first met her abductor, Bauerzhan, while hanging out with some male and female friends at a café near her office. She was 19 and worked as a receptionist in a government office. Several of the young men she worked with were friends with Bauerzhan. The 
next day, they told her that he thought she was really beautiful and that he was falling in love with her. The same friends answered all of his questions about her reputation and her family. Bauerzhan, however, did not make a positive impression on Gulmira. She did not like the fact that he was excessively drunk and crude on the day that they met. Besides, she had a boyfriend who lived in Almaty, and she hoped to marry him some day.

A few weeks later, Gulmira went to the same café with a group of young men and women whom she knew from work, and once again she encountered Bauerzhan. He was already quite drunk, and she tried to avoid him as much as possible. When it was time to go home, her co-workers proposed that they all share a taxi. She did not realize until later that some of her male co-workers were involved in the plot to abduct her. They explained that they would take Bauerzhan home first since he was so drunk, and then they would take her home. When they got to Bauerzhan's house, she was forced out of the car and into his family's house. She was absolutely furious when she realized that her friends had deceived her, and that she had been abducted by somebody that she did not like. In her own words, she intentionally 'acted like a wild woman' when anybody in the house tried to talk to her. She kept screaming and kept telling them that she wanted to leave. The women in the house tried to get her to put on a kerchief that would symbolize her acceptance, but she kept pushing it away. They tried to get her to write a letter to her parents, falsely explaining that she agreed to this marriage, but she refused to take the paper. She also rejected anything they offered her to eat or drink. She believes that they expected her to calm down after a while, as many abducted brides do, but she kept this up for hours. She refused to listen to the women's arguments about how Bauerzhan was a nice man, and how her life would be ruined if she refused to stay.

Eventually, Gulmira agreed to write a letter, knowing that it would be taken to her family. Once her own relatives arrived, she thought that she could explain that the letter was a lie, and then they would help rescue her from this situation. As she handed the letter to Bauerzhan's aunt, she angrily told them her plan to leave once her relatives showed up. Bauerzhan's relatives, however, heard this and decided that they should wait a while before sending an apology delegation to her house. They knew that the longer she stayed at their house, the more difficult it would be for her to leave. Once word got out that she had been abducted, her reputation would be tarnished, and people would question whether she was still a virgin. It did not matter whether she was or she was not. What mattered is that people would no longer be sure. While Gulmira was anticipating the arrival of her relatives, her parents were frantically trying to find her. The morning after she was abducted, her mother went to her workplace to see what she could learn. Around this same time, Bauerzhan's family informed her that they never sent the first note to her parents, and they asked her if she had reconsidered her options now that she had spent the night at their house. She told them that she did not care about the consequences, and that she still did not want to become Bauerzhan's wife.

His relatives finally accepted her decision, and let her write a second note to her parents, in which she told them to come quickly. Although some parents encourage their daughters to stay as a way to restore family honour, Gulmira's parents agreed to let their daughter return home. Her parents hoped that friends and neighbours would not find out about the abduction, so that her reputation (and their honour) would not be affected. Unfortunately, however, they learned that gossip travels fast, when Gulmira's aunts from a nearby village showed up the next day, having already heard the news. Despite their efforts to come up with explanations for her disappearance, 
Gulmira and her parents were unable to control the gossip about her abduction. Several years after I heard Gulmira's story, our mutual friend told me that she was still unmarried. Her fate sadly seems to confirm what people say about girls who return home after an abduction, but more research is required truly to understand what happens to the small number of women who avoid these unwanted marriages.

In trying to make sense of these stories, I was forced to reconcile an interesting paradox: many of the Kazakhs whom I interviewed find it to be very troubling when men abduct young women against their will, yet they also believe that an abducted woman should accept the marriage. In order to understand people's current views towards bride abduction and to explain how these views intersect with cultural constructions of the nation and modernity, it is first necessary to appreciate what Kazakh marriage practices and gender relations were like in the pre-Soviet past, and how people believe they changed during the Soviet period. In post-Soviet Kazakhstan, new discourses about women's position in society have emerged as people grapple with the legacy of Soviet rule and the challenges of the post-Soviet transition. These new discourses re-examine women's role in the workplace and the family, women's dress and decorum, and the legal future of previously banned practices such as polygyny. Much of the discourse is generated through comparisons between gender roles that people imagine about the pre-Soviet past, gender ideals created by the Soviet state, and gender images from the West. Just as Anagnost argues that the 'the nation's impossible unity in the present rests on its (re)narrativization of the past' (1997: 2), contemporary discussions about bride abduction are thus anchored in contested memories of fomer marriage practices.

\section{The historical context of bride abduction}

The Kazakhs are descendants of nomadic Turkic and Mongol tribes who formerly occupied the Eurasian steppes. Islam was first brought to the territory that is now Kazakhstan by Arab conquerors in the eighth century, but it was not until the fifteenth and sixteenth centuries that Sufi dervishes converted many of the Kazakhs to Islam. Kazakh nomads had a gendered division of labour, where men were expected to care for livestock and defend the territory while women cooked, cleaned, took care of children, served guests, and prepared textiles (Bacon 1980 [1966]). Ethnographic accounts of pre-Soviet life suggest that most Kazakh marriages were arranged by family members when the bride and groom were still young children. The bride and groom often did not meet more than once or twice before their wedding night (Argynbaev 1978; Taizhanov 1995). Marriages were exogamous, in that the bride and groom could not be related within seven generations on the male side of the family. The groom's family paid bridewealth in the form of cattle to the bride's relatives, and the bride's family provided a dowry that included a yurt, household goods, clothing, and jewellery. These exchanges strengthened relationships among specific groups of in-laws, while simultaneously establishing ties between different tribal lineages. With the exception of the youngest son, who stayed in his parents' yurt, the bride and groom received their own yurt upon marriage, which was then erected within the groom's father's camp. Once married, young brides were expected to provide in-laws with household services and to have children.

Although arranged marriages were the norm, the historical and ethnographic record indicates several exceptions to this state of affairs. For example, older men sometimes made their own matches, especially when taking on a second or third wife. In addition 
to polygyny, the Kazakhs had a custom of levirate (Argynbaev 1978). In the pre-Soviet period, bride abductions were an unusual occurrence. Grooms would abduct brides in situations where the bride's father refused a marriage, disliked the groom's family, demanded an excessively high bridewealth, and/or violated the matchmaking agreement (Argynbaev 1978; Martin 2001; Taizhanov 1995). There were also situations where a groom wanted to marry a particular girl, but she was already betrothed to another man (Taizhanov 1995). At least one source hints that some of these 'abducted brides' might have played a role in planning their own abduction (Bacon 1980 [1966]). Among the nearby Kyrgyz, the historical record suggests that non-consensual bride abductions were infrequent and were punished by customary law (Kleinbach \& Salimjanova 2007).

After nearly two centuries of increasing Russian influence, the territory of presentday Kazakhstan was incorporated into the Soviet Union in 1920. Within just a few years, the Russian-dominated Bolshevik leaders began a campaign against Central Asian traditional customs. Beginning in the early 1920s, the state passed laws that banned various 'crimes of custom'. Many of these crimes were practices that related to marriage such as the payment of bridewealth, polygyny, child betrothals, levirate, and forced marriages (Massell 1974). The new state also set the minimum legal age for marriage at 16 , initiated a campaign against women's veiling practices, and created new conditions to increase gender equity in education and employment. State efforts to emancipate women initially encountered local resistance. In the early years of Soviet rule, in particular, there was often a significant gap between Soviet policy and actual practice (Kamp 2008; Northrop 2004). For example, it was not uncommon for a man to marry multiple women, but only register one as his official wife.

Despite such discrepancies between policy and practice, there is no doubt that women's lives in Central Asia were transformed by the end of Soviet rule, which succeeded in creating the legal equality of the sexes. In the early 1920s, similar to most Kazakh men, the vast majority of Kazakh women were illiterate and uneducated. By the eve of the revolution, many Kazakh families were still relying on nomadic pastoralism to meet most of their subsistence needs. Women did not work outside of the home, though some may have earned income by selling home-made products (Werner $2004 b$ ). By the time the Soviet Union dissolved in 1991, 96 per cent of Kazakh women were literate, 52 per cent of university students in Kazakhstan were female, and approximately 90 per cent of women between the ages of 30 and 50 were employed (Bauer, Boschmann \& Green 1997). These transformations were accompanied by increasing changes to marriage practices such that both men and women played a much more significant role in selecting their own marriage partner by the end of Soviet rule. Although the Soviet state criminalized arranged marriages and bride abduction, these practices did not disappear. Instead, they were altered in unintended ways, much like the persistence and transformation of clan identities (Schatz 2004). The changing nature of these practices increasingly fits within the legal framework established by the Soviet state. The gendered effects of Soviet rule are still being unravelled by scholars, who acknowledge that, despite these achievements, the state failed to transform the domestic division of labour or significantly reduce fertility rates (Kandiyoti 2007).

In 1991, the Kazakh Republic of the Soviet Union became an independent nationstate. The newly independent Republic of Kazakhstan is a multi-ethnic state with over fifteen million citizens. By the end of the Soviet period, women were accustomed to a state that provided a number of economic and social benefits for women: free education, guaranteed employment, generous maternity leaves, free day care, and monthly 
supplements for women with children. Post-Soviet women are coping with the realities of an economy where the state has terminated its social contract with women and transferred many of the costs of social reproduction to the household level (Zhurzhenko 2004). Local and international NGOs have emerged to address various women's issues, including women's poverty and violence against women.

Several scholars note that post-socialist states have nationalist agendas that promote the 're-traditionalization' of society (Gal \& Kligman 2000). Kazakh nationalism gained momentum in the late Soviet years when Gorbachev's glasnost' policies fostered a re-examination of Soviet policies towards the Kazakhs. Although the post-Soviet Kazakhstan government remains secular and wary of Islamic fundamentalism, there is a growing acceptance of Islam as an important element of Kazakh national identity (Michaels 1998). Throughout Central Asia, gender relations are being redefined as Islamic values are reinstated as the 'guiding ethic for society', national histories and national traditions are rewritten and revived, and patriarchal authority (symbolized by the male head of state) is reasserted (Akiner 1997: 284; Kandiyoti 2007). Contemporary discourses on gender are also shaped by the infiltration of 'Western' fashions and lifestyles that are more sexually explicit (Akiner 1997; Kuehnast 1998; Michaels 1998; Tadjbaksh 1998). Now that the rigid borders separating East and West are gone, Kazakhs are purchasing European fashions, watching Latin American telenovellas, and travelling abroad for trade, adventure, and study. These experiences in the 'global village' contribute to the need to distinguish and maintain what is uniquely Kazakh.

Marriages in the contemporary period reflect these public debates regarding gender roles and gendered behaviour. On the one hand, there has been a slight revival of arranged marriages as a 'traditional' Kazakh practice, especially among the economic elite, who can afford the associated expenses. These marriages sometimes start as a conversation between parents when the children are young; however, all of the arranged marriages that I learned about involved the full consent of the bride and groom. I also encountered arranged marriages that were initiated by a young couple who asked their parents to 'arrange' the marriage. On the other hand, there has been a significant increase in non-consensual bride abductions. Consensual abductions still occur regularly, but it is increasingly common for the groom to use some form of deception in order to kidnap a woman. It is important to note that bride abduction is not an Islamic practice, and unlike female circumcision practices, where some local actors wrongly associate the practice with Islam (Walley 2006), people in Kazakhstan and Kyrgzystan do not link bride abduction and religious custom.

The recent increase of non-consensual bride abduction cases has been documented in both Kazakhstan and Kyrgyzstan, yet the issue has received more political attention in Kyrgyzstan, prompted by Western scholars, non-governmental organizations, and local government officials. The issue clearly moved beyond scholarly attention with the distribution of the film Bride kidnapping in Kyrgyzstan. While teaching at a university in Kyrgyzstan, Peter Lom, a European philosophy professor, decided to bring greater awareness of bride abduction by producing this film. First broadcast in March 2004 as a twenty-minute segment to a US audience on PBS's Frontline show, the film was expanded later that year to fifty-one minutes (Lom 2004a; 2004b). In collaboration with local scholars and local NGOs, international NGOs have also started to press the government to take steps to address this issue. In 2006, for example, Human Rights Watch (2006) published a 140-page report on the problems of domestic violence and bride abduction in the Kyrgyz Republic. Among other things, the report recommends 
that the Kyrgyz government enforce existing laws, compile statistics on unlawful abductions, establish a nationwide public awareness campaign, provide assistance for victims of bride abduction, and educate law enforcement officers. The United Nations Population Fund (UNFPA) (2007) has also published a fact sheet on bride kidnapping in Kyrgyzstan, and has included this issue in its gender equality programmes. In response to all of these developments, the government has acknowledged the problem, and held a public hearing on the problem of bride kidnapping in April 2007, organized by the Human Rights Commission of the Government of Kyrgyzstan. ${ }^{4}$

In comparison, the issue of non-consensual bride abduction has gone relatively unnoticed in Kazakhstan. One Kazakhstani umbrella organization, Silk Road Women, mentions that bride abduction takes place in Kazakhstan (as well as Kyrgyzstan), ${ }^{5}$ yet affiliated non-governmental organizations give much more visibility to the problems of trafficking women from Kazakhstan to other countries (Snajdr 2005). In a report by the Women's Environment and Development Organization (WEDO) on the status of women after the 1995 Fourth World Conference on Women in Beijing, the authors acknowledge that bride abduction is a form of 'culture-based violence against women' in both Kazakhstan and Kyrgyzstan. The report also notes that the new Kazakhstani Criminal Code, which came into force on 1 January 1998, dropped a previous clause that criminalized the abduction of women against their will (WEDO 2005: 59). Meanwhile, the international NGOs who describe this problem in Kyrgyzstan, including Human Rights Watch and the UNFPA, have not made it a priority issue for Kazakhstan. And the international media has only covered this practice in Kyrgyzstan (Lloyd-Roberts 1999; Smith 2005). One possible exception is the recent comedy Borat: cultural learnings of America for make benefit glorious nation of Kazakhstan (2006), in which the lead character, the fictional journalist 'Borat', attempts to marry Pamela Anderson by forcibly abducting her from a bookstore. Since the film contains so much ridiculous content known to be fictional, such as the 'Running of the Jew' festival, the audience is likely to assume that the practice of bride abduction is also fictional.

\section{Shame and the decision to stay after an abduction}

I now want to turn to the issue of how people talk about a woman's decision to accept or reject a marriage after being abducted against her will. Although most women feel pressured to accept the marriage, some women (like Gulmira above) decide to return home. Many of the same people who told me that they believe it is wrong for a man to abduct a woman without her consent also believe that it is wrong for an abducted woman to reject the marriage. These seemingly paradoxical views were held by both men and women. When I pointed out this apparent contradiction to one of my research assistants, she told me two proverbs that Kazakhs cite in reference to abducted brides. The first proverb, 'Attap bosqan bosagha - altyn bosagha', can be translated as 'The threshold that has been crossed is the golden threshold'. The second proverb, 'Birinshi baq baq, ekinshi baq qai baq, o beibaq?!', is best translated as 'A first happiness [marriage] is happiness, a second happiness [marriage] is what kind of happiness? - no happiness!' As she explained, both proverbs indicate that it is a woman's fate to stay and that it is 'bad luck' for an abducted bride to return home.

Not only is it bad luck, but many Kazakhs believe that it is shameful for an abducted bride to return. A woman who rejects the groom will then be known as a 'qaittyp kelgen $q y z$ ' ('a girl who returned home'). The significance of this stigma is best understood 
within the broader context of honour and shame, where a family's honour is linked to female modesty. Anthropological theories on honour and shame can help us understand why a woman would feel that she has little choice but to stay, and why parents who love their daughter dearly would also believe that this is the best decision. Anthropologists working in the Middle East have long noted the link between male honour and female sexuality (Abu-Lughod 1986; 1993; Wikan 2008). A family's reputation can be damaged if a daughter, wife, or sister conducts herself inappropriately. Even unconfirmed rumours about inappropriate behaviour can dishonour a family. The important thing is the public knowledge of the transgression or the rumour (Wikan 2008: 6). Although the concepts of honour and shame resonate strongly throughout the Muslim world, there is great variation across time and space in what is considered to be appropriate female behaviour and the extent to which men (and women) respond to behaviour that is perceived to be shameful (Wikan 2008: 49). Among Kurdish immigrants in Sweden, for example, a young woman who disgraces her family by dating a Swede might be killed by her own male relatives. Attitudes towards such killings vary within the Kurdish community, and change depending on the circumstances. According to Wikan (2008: 52-7), immigrant women probably face greater risks of being a victim of honour killing than women who remain in Turkey, because the men feel more threatened by the prospect of cultural assimilation.

Anthropological theories about honour relate to bride abduction because the majority of societies with bride abduction place a high value on virginity. Stross, for example, suggests that a Tzeltal woman kidnapped against her will cannot prove that she is an unwilling victim. Further, '[o]nce kidnapped her reputation in the community changes irrevocably. She is presumed to have been violated sexually and is no longer worth much of a bride price if any' (1974: 341-2). According to the Kazakhs I interviewed, a woman's reputation is publicly questioned after she has been abducted. As Wikan (2008) argues, the reality of the situation matters much less than the fact that the possibility has entered the public conscious. This explains why Gulmira's family tried so hard to suppress the gossip about their daughter's abduction. In addition to having a dubious sexual reputation, a woman who 'returns home' is considered to be stubborn and belligerent, and therefore less desirable as a marriage partner (and a daughter-inlaw). Although people might sympathize with the difficult situation faced by an abducted woman, many believe that she is better off accepting the marriage than provoking the shame that would befall her and her family if she came home.

When a woman is forcefully abducted, these cultural beliefs are invoked in persuasive performances to pressure the bride to accept the marriage. This social pressure comes from a variety of sources: the groom and his accomplices, the groom's relatives, and the bride's relatives. By accepting the marriage, the bride restores honour to her own family, while simultaneously preventing shame from falling upon the groom's family. Social pressure from the groom and his accomplices may include violence or threats of violence. For example, a young Kazakh woman recounted how her neighbour was abducted by a group of men who threatened to rape her if she shamed the groom by declining the marriage. She was afraid and felt like she had no choice but to accept the marriage. After the groom and his accomplices bring the bride to his house, his female relatives play an important role in convincing the bride to stay. His mother, aunts, and sisters-in-law all remind her of the shame and unhappiness that will certainly befall her if she chooses to return home. After the groom's family informs the bride's family of her whereabouts, these same arguments are often reiterated by 
members of the bride's family. By pressuring the bride to stay, these older, married women are helping to reproduce patriarchal institutions in a way that is reminiscent of Deniz Kandiyoti's (1988) concept of the 'patriarchal bargain' under conditions of classic patriarchy. Bride abduction therefore is not a simple act of male dominance over women, as women also help to reinforce male dominance.

At the same time, alternative voices do exist, and offer emotional support to the victims of non-consensual abductions. Some women, like Gulmira's mother, support their daughter's decision to reject an unwanted marriage. Further, brides abducted against their will are not passive agents. Borrowing Foucault's (1990 [1976]) idea that the existence of power engenders resistance, I argue that Kazakh women often enact their own performances of resistance in response to the power of shame that suggests they should stay. These forms of resistance may or may not succeed, and abducted women need to act quickly if they want to avoid an undesirable marriage. As a general rule, unmarried women are warned to avoid rides from men, even with close acquaintances. Despite the known risks, however, they cannot always resist the convenience of a car ride over the unreliable and slow alternative of using mass transportation or walking. Once a woman realizes that she is being kidnapped, she may try to get out of the situation. Lazzat, a 20-year-old woman, told me about how she talked her way out of a kidnapping situation. One night, she and a female friend agreed to ride with their male friend Yerlan to a wedding. When Yerlan started to drive in the wrong direction, Lazzat feared that he was planning to abduct her. She reminded him that he was a 'modern college-educated' man, and that men like that do not abduct women. He was persuaded by her argument, and news of the aborted abduction did not get out. Another woman, Madina, jumped out of a moving car in order to escape her abductor. Neither of these women were labelled as a 'girl who returns home', because they were able to escape before they were brought into a public setting with lots of witnesses.

After a bride crosses the threshold into the groom's house, she still has several opportunities to resist the marriage. Upon arrival at his house, a female member of the groom's household usually presents the bride with a kerchief (oramal). Since married women traditionally wore a kerchief over their hair, the bride's acceptance of the kerchief is a public sign that she is willing to marry the groom. Although willing brides do not want to appear too eager to take the scarf, they often put it on within the first hour or two. Brides who are abducted without their consent might not put the scarf on for hours or even days.

Shortly after her arrival, a bride is also asked to write a letter to her family stating that she came of her own free will. Taken to her parents as evidence that she accepts the marriage, the letter provides another opportunity for the bride to express her resistance. I talked to several abducted brides who were completely distraught for hours, screaming at anybody who approached them, throwing things around the room, and even breaking windows. Aigerim, for example, was kidnapped when she was 20 years old. When asked to write a letter, she repeatedly wrote: 'I don't want to stay here! I did not agree to this!' The groom's aunts kept telling her that they could not take this note to her parents. They kept bringing her a fresh piece of paper and dictated the words that they wanted her to write. Eventually, she gave in and wrote the letter, though it took several months before she accepted her husband's friendly gestures.

Such acts of resistance often fail, but occasionally an abducted bride is rescued by her parents or even released by the groom's parents. As one informant told me, a distraught bride should also try to send an urgent message to her family via a friend who 
accompanied her to the groom's house or an ally in the groom's house. In one unusual case, an abducted woman managed to send a message to her boyfriend, who then came to her rescue. Instead of returning to her parent's home, she escaped from her abductors' home in order to marry the young man whom she loved. Suggesting that this was not the proper way for a Kazakh woman to behave, one middle-aged man suggested that this woman was probably influenced by all of the 'Mexican' soap operas that were broadcast in Kazakhstan after the fall of the Soviet Union. He even decided that the women in his household should not be allowed to watch these programmes for a while. This particular abduction demonstrates that some women are successfully able to resist these marriages, though they may be publicly criticized for what some might consider as subversive acts.

\section{Questioning the historical authenticity of bride abduction}

The second contentious issue is whether non-consensual bride abduction is a practice with roots in the pre-Soviet past, or whether it is a new manifestation of a practice that has transformed over the decades. When I asked people in Kazakhstan to talk about the origins of bride abduction, most people seemed to believe that arranged marriages were the dominant norm and that bride abductions were unusual in the pre-Soviet past. Several respondents were even concerned that non-consensual bride abduction was a shameful practice for Kazakhstan as it conflicted with their notion of what a 'modern' state should look like. This idea is well illustrated by a letter published in a national women's magazine, Qazaqstan Aiyelderi, in 2001. Written by Elmira, a 16-yearold girl from a village in Almaty province, the letter asks the editors to speak about the legitimacy of this practice:

\footnotetext{
Our Kazakh people, from ancient times, cherished and lavished attention on, and especially respected, girls. Among Kazakhs, don't we have an expression that 'a daughter is a guest'? And, for our nationality, isn't one of the basic traditions to give the daughter by hand to the groom, and to send her off following the ancient rites? If so, why now is it so rare to see the tradition where the girl is given by hand to the boy? And in its place, you often see a girl being abducted, and if she stays, the marriage scarf is placed on her head. Does this way of uniting couples count as a Kazakh tradition? Could it be that this method has been modified in the contemporary period? If a girl throws down the marriage scarf that has been placed on her own head by force, and she leaves without spending the night, then isn't there a spiritual expression that states that the girl will not be happy her entire life? I look forward to your answers to these questions.
}

In their response, the editors point out that there are two different types of bride abduction (consensual and non-consensual), and stress that women should not accept the marriage if they are not in love with the groom. Although the editors did not fully address Elmira's question about whether this practice has changed in the contemporary period, several of the people I interviewed had detailed explanations for how marriage practices had changed in the twentieth century. In reference to pre-Soviet traditions, one woman in her twenties explained that bride abductions in the past were limited to cases where the bride's parents objected to the marriage. In such cases, a woman might have used abduction as a way to resist the patriarchal norm of arranged marriage by conspiring with her intended groom. In another variation of pre-Soviet abductions, a woman told me that men from poor families were able to marry women from wealthier families by abducting a bride.

Most of the Kazakhs I interviewed believe that marriage practices changed significantly during the Soviet period, though they do not always agree on how and when 
these changes took place. One middle-aged woman, for example, believed that bride abductions became more popular after collectivization (in the 1930s) because families could no longer afford bridewealth. In contrast, two elderly women who got married in the 1940 mentioned how marriages at that time were often still arranged by parents without the daughters' input. Others noted that arranged marriages became less common in the 1950s, and transformed in nature. To varying degrees, parents still tried to influence the process, by initiating certain introductions and by offering or denying their consent. But, increasingly, children were allowed to express their opinion about these matches. As one woman explained, some young couples met on their own, and then later asked their parents to go through the formality of 'arranging' the marriage, which entailed an elaborate exchange of gifts and dinner parties between the in-laws.

As arranged marriages decreased in frequency between 1950 and 1970, two alternative forms of marriage gained in popularity: non-traditional 'Komsomol' marriages and bride abductions (Werner 2004a). A Komsomol marriage was a frugal wedding, encouraged by the Communist Party and centred on an official ceremony at the civil registry. At the same time, new manifestations of bride abduction were compatible with both Kazakh gender norms and Soviet values, and provided a more economical wedding than an arranged marriage. A middle-aged woman explained how bride abduction resolved a conflict between traditional Kazakh values and Soviet values. For her, according to traditional Kazakh values, unmarried women were expected to listen to their parents and their elders when it came to their marriage choices. Women who were 'abducted' did not appear to be 'running away' with a boyfriend and thus elders regarded them as appropriately modest. At the same time, Soviet values encouraged women to select marriage partners on their own; and they did, as long as the abduction was planned and staged, sometimes with the help of both sets of parents. Several respondents told me that bride abductions during the Soviet years rarely involved deception or force, unlike many of the more recent bride abductions (Werner 2004a). For families with less income and fewer resources, bride abduction provided an alternative that reduced and delayed some of these new wedding costs, without eliminating all of the expected celebrations. Bride abductions surged in popularity in the 1970s, a time when average wedding expenses increased. Today, people still cite the cost of weddings as a primary reason for abducting a bride, rather than having an arranged marriage.

Although qyz alyp qashu serves as a general concept that can be used to describe a variety of situations, many Kazakhs make a strong moral distinction between consensual and non-consensual bride abduction. In describing a case where a young woman was abducted by a complete stranger, a woman in her thirties expressed strong sympathy for the bride, who was not able to marry the person she loved. One middle-aged man even worried that my interest in bride abduction could bring international awareness to a practice that he considered to be shameful for ethnic Kazakhs. He thought it was important to clarify that most bride abductions, including his son's marriage, involve the consent of the bride. I also encountered several men, including a rural judge and a Kazakh student in the United States, who flatly denied the existence of nonconsensual abductions. Either these men are truly unaware of the nature of some abductions, or they are also trying to protect their national culture. For many, consensual bride abduction is viewed favourably because it is based on a love match. This idea is reflected in the editorial response to Elmira's question in Qazaqstan Aiyelderi: ' $[\mathrm{W}]$ hen a girl is abducted forcibly, it is not love, it is infatuation, complete infatuation'. 
The perceived morality of a consensual abduction, however, can vary depending on one's individual position. For example, when a young couple elopes without the parents' consent or knowledge, the bride's parents are often upset that their daughter made this decision, especially in cases when they had their own preference for whom she should marry.

Answers to my questions about bride abduction were certainly influenced by my position as a Western, female anthropologist, as well as by the context of the interview. I find it interesting that so many people I interviewed were willing to make moral judgements against non-consensual abductions, whereas people in Kyrgyzstan seem more likely to defend the practice to Western scholars. The only people who spoke in favour of non-consensual bride abductions were young men who admitted that they had participated in several such acts. A group of three young men were so unabashed when it came to describing abductions of women who were struggling to free themselves that I had to wonder whether they were embellishing their stories for my benefit. They did not think it was important for the woman to consent to the marriage ahead of time, because she would 'become happy after a week or so' (Werner 2004a).

Although an anthropological perspective would question the very notion that 'traditions' remain constant, local beliefs about the historical authenticity of bride abduction can have important political implications. As the Human Rights Watch report states, 'A consequence of regarding bride kidnapping as a tradition is that it becomes part of the unwritten social charter and is deemed above criticism' (Human Rights Watch 2006). In other words, activists who oppose non-consensual abduction are likely to have a stronger case if they can demonstrate that this is a new practice, or a newly manifested version of an older practice. Regarding this issue, there appears to be a significant discrepancy between what people are saying in Kazakhstan, where bride abduction is more concentrated in the southern provinces, and what people are saying in Kyrgyzstan, where bride abduction is geographically widespread.

In Kyrgyzstan, there seems to be a strong divide between the public notion that bride abduction is a traditional practice and the scholarly opinion that non-consensual abduction was rare in the past. In one survey conducted in northeastern Kyrgyzstan, 38 per cent of respondents replied that a particular bride was abducted because ' $\mathrm{t}]$ his is a good traditional way to get a bride' (Kleinbach et al. 2005). According to the authors, these findings suggest that bride abduction is viewed as a culturally acceptable practice that has been revived from pre-Soviet times. In a different survey conducted in the Jalalabad region, 40 per cent of adults interviewed believe that non-consensual bride abduction was practised in the early twentieth century (Kleinbach \& Salimjanova 2007). Handrahan adds that bride abduction has 'become a primary act defining cultural identity and manhood' (2004: 208). Men are able to claim their Kyrgyz ethnicity by establishing their dominance over women while abducting a Kyrgyz bride, while Kyrgyz women identify their loyalty to their ethnicity by accepting this act of violence (Handrahan 2004).

This is not to say that all Kyrgyz believe that non-consensual bride abduction is a national tradition. In addition to the 60 per cent who did not feel that bride abduction was a tradition in the pre-Soviet period, Kleinbach and his collaborators have interviewed dozens of scholars, the majority of whom disagree with the popularly held belief that this is a revival of a customary practice from the pre-Soviet past. Instead, these scholars believe that non-consensual abduction was very rare in pre-Soviet times, and on many occasions it did involve the consent of the bride, against the will of her parents 
(Kleinbach \& Salimjanova 2007). As evidenced by the surveys described above, these beliefs are not limited to scholars, though both Kleinbach and Handrahan emphasize that the popular belief is that non-consensual bride abduction is a national tradition.

\section{Conclusion}

Although violence against women can be found in all societies, certain patterns of violence, such as female genital mutilation and honour killings, have been defined as 'culturally determined' practices (Penn \& Nardos 2003: 87). As transnational feminists and local NGOs take steps to change these practices, conflicts often arise between activists who attack gender-based violence in defence of human rights and local community members who justify these practices in the name of culture (Merry 2006). Feminist understandings of gender-based violence emphasize that violence serves as a mechanism for men to assert and maintain power over women. The threat of potential violence in any cultural setting where men regularly commit acts of violence against women has the affect of controlling or limiting women's behaviour (Maynard 1993). In the case of bride abduction, shame is the key concept employed in discussions about whether an abducted woman should accept or reject a marriage. Even people who believe that an abducted woman should not have to stay with her abductor believe that this act of resistance will bring shame to her and her family. Women who accept a marriage after being abducted avoid the shame that is inflicted on women who decide to reject a marriage.

The concept of shame is not novel to Central Asia, yet how shame is being used to delineate appropriate gendered behaviour in contemporary society represents a break with the Soviet past. During the Soviet period, the state promoted gender equality and Kazakh women were encouraged to make their own decisions about whom they wanted to marry. And many of the people who married in the 1970 in particular insist that brides were only abducted with their consent during this time period (Werner 2004a). At that time, the act of abducting a bride without her consent would have been shameful for the groom. In the post-Soviet period, the state has different priorities, such that the construction of a national identity has assumed more importance than the Soviet goal of achieving gender equality. The nation-building project in the present involves a 're-narrativization of the past' (Anagnost 1997), and this process tends to romanticize ideal gender relations that may or may not have actually existed in the pre-Soviet period. Although neither men nor women had much control over their marriage choices, collective memories of the past tend to place more emphasis on the limited choices of women. In addition to the impact of post-Soviet nationalism, discussions of proper behaviour today can also be viewed in part as a reaction to the infiltration of 'Western' fashions and lifestyles (Kuehnast 1998; Michaels 1998). It is not uncommon for Kazakhs to be concerned about these images of the West, as evidenced by the reaction to Western soap operas discussed above. If young Kazakh women were to be influenced by these images of the West, their sexuality would bring shame to their families. Such fears therefore justify the need to reassert male control over female sexuality.

In addition to the concept of shame, it is important to consider how popular conceptions of 'tradition' mark a shift towards patriarchy. Local understandings of non-consensual bride abduction in both Kazakhstan and Kyrgyzstan are contested and negotiated in political environments where civil society, with its ties to transnational flows of ideas and resources, has taken over the state's role as the defender of women's rights, and where state and non-state actors have fostered a sense of pride in national 'traditions'. Throughout the world, acts of violence against women are often defended in 
the name of culture, with the result that efforts to change these practices become framed as a struggle between culture and human rights (Merry 2006). This is the case with female circumcision, where some community actors invoke cultural beliefs in support of these practices (Walley 2006). What is interesting about non-consensual bride abduction in Central Asia is that the notion of whether this is a national 'tradition' varies from one country to the next. In Kazakhstan, most Kazakhs recognize that this practice has changed significantly over time, and they do not view it as their traditional form of marriage. In contrast, there is a relatively strong public perception in neighbouring Kyrgyzstan that bride abduction is a national tradition that was suppressed during the Soviet period (Kleinbach \& Salimjanova 2007). As Anagnost argues, '[I]nterest in the past originates out of concerns of the present' (1997: 5). In the case of Kyrgyzstan, popular efforts to re-imagine a past where men routinely abducted women to become their wives are part of a larger political process in the present where the new nation-state seeks to signal a sharp break with the Soviet past. Although the practice is contested, this form of violence against women has become associated with Kyrgyz identity. In Kazakhstan, there are also efforts to re-imagine the national traditions, though this process does not yet involve a belief that bride abduction was a common marriage practice in the past. In both countries, post-Soviet discourses of shame and tradition are shifting power relations between men and women in ways that increase male control over female mobility and female sexuality. These processes are more pronounced in Kyrgyzstan, owing to a stronger belief in the historical legitimacy of bride abduction.

\section{NOTES}

This article is based on ethnographic fieldwork in Southern Kazakhstan province. During interviews with over sixty Kazakh women and men, I asked them to talk about marriage practices in the past and the present. I interviewed people from varying ages and social backgrounds, in both rural and urban settings. I attended dozens of Kazakh weddings, bridal showers, engagement parties (qudalyq), and 'face-opening' (betashar) ceremonies. I also conducted a survey that allowed me to obtain a rough estimate of the number of marriages that could be classified as bride abductions, the level of consent involved with each of these marriages, and how marriage patterns had changed over time (Werner 2004a).

Research for this article was funded by the Social Science Research Council and the National Council for Eurasian and East European Research. A fellowship from the Melbern G. Glasscock Center at Texas A\&M provided the necessary time to write an early version. Special thanks to Simon Coleman, Madina Kenzhegaranova, Pauline Jones Luong, Kelly McMann, Neha Vora, and the anonymous reviewers for JRAI for providing comments on various versions of this article. I would also like to acknowledge Aigul Baituova, Tarbiye Orazbekova, Maria Parks, Andy Scherer, Zhanna Torebaeva, and Kamshat Torebaeva for their assistance with this project.

${ }^{1}$ Pseudonyms are used throughout this article.

${ }^{2}$ Although Kazakhs distinguish between an unmarried 'girl' (qyz) and a married 'woman' (aiyel), I use the term 'woman' in this article to refer to both unmarried and married women.

${ }^{3}$ The issue of consent (kelisim) is not straightforward. First, there is the issue of who is consenting to the marriage: the bride, the groom, the bride's family, or the groom's family. Second, there is the issue of what the bride has consented to: an interest in the groom, an interest in marrying the groom at some future time, or an interest in marrying the groom right now. I frequently heard of cases where the abducted bride had expressed interest in marrying the groom some day, but not right away. In these cases, I argue that the term 'semi-consensual' might be more appropriate (Werner 2004a).

${ }^{4}$ I would like to thank Madeleine Reeves for bringing this event to my attention.

${ }^{5}$ The website for this organization is no longer functioning.

\section{REFERENCES}

Aвu-Lughod, L. 1986. Veiled sentiments: honor and poetry in Bedouin society. Berkeley: University of California Press. 
1993. Writing women's worlds: Bedouin stories. Berkeley: University of California Press.

AheArn, L.M. 2001. Invitations to love: literacy, love letters, and social change in Nepal. Ann Arbor: University of Michigan Press.

AKINER, S. 1997. Between tradition and modernity: the dilemma facing contemporary Central Asian women. In Post-Soviet women: from the Baltic to Central Asia (ed.) M. Buckley, 261-304. Cambridge: University Press.

Amslen, S. \& R. Kleinbach 1999. Bride kidnapping in the Kyrgyz Republic. International Journal of Central Asian Studies 4, 185-216.

Anagnost, A. 1997. National past-times: narrative, representation and power. Durham, N.C.: Duke University Press.

Argynbaev, K. 1978. Marriage and marriage rites among the Kazakhs in the nineteenth and early twentieth centuries. In The nomadic alternative: modes and models of interaction in the African-Asian deserts and steppes (ed.) W. Weissleder, 331-41. The Hague: Mouton.

Ayres, B. 1974. Bride theft and raiding for wives in cross-cultural perspective. Anthropological Quarterly 47, $238-52$.

BACON, E. 1980 [1966]. Central Asians under Russian rule: a study in culture change. Ithaca, N.Y.: Cornell University Press.

Barnes, R.H. 1999. Marriage by capture. Journal of the Royal Anthropological Institute (N.S.) 5, 57-73.

BATES, D.G. 1974. Normative and alternative systems of marriage among the Yoruk of Southeastern Turkey. Anthropological Quarterly 47, 270-87.

Bauer, A., N. Boschmann \& D. Green 1997. Women and gender relations in Kazakstan. Manila: Asian Development Bank.

Foucault, M. 1990 [1976]. The history of sexuality, vol. I (trans. R. Hurley). New York: Vintage.

GAL, S. \& G. KLIGMAN 2000. The politics of gender after socialism. Princeton: University Press.

HANDRAHAN, L. 2000. Implications of international human rights law and bride kidnapping in Kyrgyzstan. Praxis: The Fletcher Journal of Development Studies 16, 97-114.

2004. Hunting for women: bride-kidnapping in Kyrgyzstan. International Feminist Journal of Politics 6, 207-33.

Human Rights WATch 2006. Reconciled to violence: state failure to stop domestic abuse and the abduction of women in Kyrgyzstan, 27 September (available on-line: http://hrw.org/reports/2006/kyrgyzstanogo6/, accessed 12 February 2009).

KАMP, M. 2008. The new woman in Uzbekistan: Islam, modernity and unveiling under communism. Seattle: University of Washington Press.

KANDiyoti, D. 1988. Bargaining with patriarchy. Gender and Society 2, 274-90.

2007. The politics of gender and the Soviet paradox: neither colonized, nor modern? Central Asian Survey 26, 601-23.

KLeINBACH, R. 2003. Frequency of non-consensual bride kidnapping in the Kyrgyz Republic. International Journal of Central Asian Studies 8, 108-28.

—, M. Ablezova \& M. Aitieva 2005. Kidnapping for marriage (ala kachuu) in a Kyrgyz village. Central Asian Survey 24, 191-202.

\& L. SAlimjanova 2007. Kyz ala kachuu and adat: non-consensual bride kidnapping and tradition in Kyrgyzstan. Central Asian Survey 26, 217-33.

KUEHNAST, K. 1998. From pioneers to entrepreneurs: young women, consumerism, and the 'world picture' in Kyrgyzstan. Central Asian Survey 17, 639-54.

LLOYD-RoвerTs, S. 1999. Kyrgyz bride theft goes awry. BBC Worldnews, 22 March.

Loм, P. 2004a. The kidnapped bride. Frontline/World, 25 March. 20 minutes.

LoM, P. 2004b. Bride kidnapping in Kyrgyzstan. First Run/Icarus Films. 51 minutes.

McLaren, A.E. 2001. Marriage by abduction in twentieth-century China. Modern Asian Studies 35, 953-84.

McLennan, J.F. 1970 [1865]. Primitive marriage: an inquiry into the origin of the form of capture in marriage ceremonies. Chicago: University Press.

MANI, L. 1998. Contentious traditions: the debate on sati in colonial India. Berkeley: University of California Press.

Martin, V. 2001. Law and custom in the Steppe: the Kazakhs of the Middle Horde and Russian colonialism in the nineteenth century. London: Curzon.

Massell, G. 1974. The surrogate proletariat. Princeton: University Press.

MAYNARD, M. 1993. Violence towards women. In Thinking feminism: key concepts in women's studies (eds) D. Richardson \& V. Robinson, 88-122. New York: Guilford. 
Merry, S.E. 2006. Human rights and gender violence: translating international law into local justice. Chicago: University Press.

Michaels, P. 1998. Kazak women: living the heritage of a unique past. In Women in Muslim societies: diversity within unity (eds) H.L. Bodman \& N. Tohidi, 187-202. Boulder, Colo.: Lynne Rienner.

Northrop, D. 2004. Veiled empire: gender and power in Stalinist Central Asia. Ithaca, N.Y.: Cornell University Press.

PenN, M.L. \& R. NARdos 2003. Overcoming violence against women and girls: the international campaign to eradicate a worldwide problem. Boulder, Colo.: Rowman \& Littlefield.

Schatz, E. 2004. Modern clan politics: the power of 'blood' in Kazakhstan and beyond. Madison: University of Wisconsin Press.

Sмith, C.S. 2005. The bridal 'grab and run'. The International Herald Tribune, 29 April.

SNAJDR, E. 2005. Gender, power, and the performance of justice: Muslim women's responses to domestic violence in Kazakhstan. American Ethnologist 32, 294-311.

Stross, B. 1974. Tzeltal marriage by capture. Anthropological Quarterly 47, 328-46.

Tadjвaksh, S. 1998. Between Lenin and Allah: women and ideology in Tajikistan. In Women in Muslim societies: diversity within unity (eds) H.L. Bodman \& N. Tohidi, 163-85. Boulder, Colo.: Lynne Rienner.

Taizhanov, G.E. 1995. Kazakhi: Istorikho-etnograficheskoe issledovanie. Almaty: Kazakhstan Publishers.

United Nations Population Fund (UNFPA) 2007. Fact sheet on bride kidnapping (available on-line: http://www.unfpa.org/16days/documents/pl_bridenapping_factsheet.doc, accessed 12 February 2009).

WALLEY, C. 2006. Searching for 'voices': feminism, anthropology, and the global debates over female genital operations. In Feminist anthropology: a reader (ed.) E. Lewin, 333-57. Malden, Mass.: Blackwell.

WERNER, C. 2004a. Women, marriage, and the nation-state: the rise of nonconsensual bride kidnapping in post-Soviet Kazakhstan. In Reconceptualizing Central Asia: states and societies in formation (ed.) P. Jones Luong, 59-89. Ithaca, N.Y.: Cornell University Press.

2004b. Feminizing the new Silk Road: women traders in rural Kazakhstan. In Post-Soviet women encountering transition: nation building, economic survival, and civic activism (eds) K. Kuehnast \& C. Nechemias, 105-26. Baltimore: Johns Hopkins University Press.

WIKAN, U. 2008. In honor of Fadime: murder and shame. Chicago: University Press.

Women's Environment and Development Organization (WEDO) 2005. Beijing betrayed: women worldwide report that governments failed to turn the platform into action. New York: WEDO. March.

Zhurzhenko, T. 2004. Strong women, weak state: family politics and nation building in post-Soviet Ukraine. In Post-Soviet women encountering transition: nation building, economic survival and civic activism (eds)

K. Kuehnast \& C. Nechemias, 23-43. Washington, D.C.: Woodrow Wilson Center Press.

\section{Mariage par rapt en Asie centrale postsoviétique : le retour du patriarcat dans le discours local sur la honte et la tradition}

Résumé

Le renouveau des enlèvements non consentis de femmes au Kazakhstan et au Kirghizstan peut surprendre, soixante-dix ans après l'interdiction de cette pratique par l'État soviétique et la mise en place d'une législation volontariste pour l'émancipation des femmes. Sur la base des discours locaux sur la honte et la tradition, l'article explique ce changement de pratiques matrimoniales et met en lumière la résurgence du patriarcat en Asie centrale postsoviétique. Les discours sur la honte sont mobilisés par les acteurs locaux à l'appui de l'idée populaire qu'une femme doit « rester " après avoir été enlevée. Les femmes peuvent résister aux enlèvements, et résistent effectivement, mais s'exposent ainsi au poids de la honte. Par ailleurs, au Kirghizstan, où le rapt des femmes est de plus en plus ré-imaginé comme une tradition nationale, les femmes et les militants qui contestent cette pratique peuvent être accusés de trahison envers leurs racines ethniques. Ces discours sur la honte et la tradition ont aidé les hommes à reprendre le contrôle de la mobilité et de la sexualité des femmes dans la société postsoviétique.

Cynthia Werner is an Associate Professor of Anthropology at Texas A\&M University. Her research interests include post-socialism, gift exchange, social networks, risk perception, and transnational migration.

Texas A\&M University, Department of Anthropology, College Station, Texas 77843-4352, USA. werner@tamu.edu 